\title{
DETECTION OF TILMICOSIN AND ENROFLOXACIN RESIDUES IN BROILER CHICKEN LIVER AND MEAT SOLED IN MARKETS AT BENHA CITY
}

\author{
ABOU ARAB, N.M. ${ }^{1}$; EL. SAID, A. EL. SAID ${ }^{2}$; THABET, M. GERGES ${ }^{1}$, and EL-KATAN, Y.A. ${ }^{3}$ \\ ${ }^{1}$ Food Control Dep. Animal Health Research Institute-Benha Branch. \\ ${ }^{2}$ Food Control Dep. Animal Health Research Institute-Shebin Elkoom Branch. \\ ${ }^{3}$ Pharmacology Dep. Animal Health Research Institute-Shebin Elkoom Branch.
}

Received: 7 February 2017; $\quad$ Accepted: 2 March 2017

\begin{abstract}
Fourty samples of broiler chicken liver and muscles (twenty samples for each) were collected from popular markets of Benha city, Kaluobia governorate, Egypt to detect and analyze of Tilmicosin and Enrofloxacin residues using of High Performance Liquid Chromatography (HPLC), and also to detect their influence by heat processes. Tilmicosin residues were detected in all examined liver samples with a mean concentration of 481.88 $\pm 54.81 \mathrm{ppb}$ while Enrofloxacin residues were detected in only $66.66 \%$ of liver samples with a mean concentration of $8.288 \pm 1.47 \mathrm{ppb}$ while all examined muscle samples were free from any detectable levels. After boiling and using of autoclave, all residues of liver samples were undetectable. This study emphasized on the importance of strict analyzing of antimicrobial residues prior to marketing and also usefulness of heat cooking with or without pressure, for complete or partial elemination of antibiotic residues.
\end{abstract}

Key words: Tilmicosin, Enrofloxacin, Residues, Broiler, Benha City.

\section{INTRODUCTION}

Extensive use of antibiotics leads to potential health problems include allergic reactions, direct toxic effects and a change in the resistance patterns of bacteria exposed to such antibiotics (Weaver, 1992 and Fabrega et al., 2008).

Many reports indicated that the resistance of microbes to antibiotics may arise from extensive adminstration of antibiotics, and this resistance may be transferred to human pathogens (Yorke and Froc, 2000). Consumers who consumed Milk, meat and eggs which have antibiotic residues for a long time that can produce bacterial resistance and therapeutic failures among them. Similarly, administration of very low doses of some drugs for a prolonged time produces reproductive and teratogenic effects (Stephen and Sundlof, 1994).

Antibiotic residues in animal derived foods have been extensively recorded in many African countries; these

Corresponding author: Dr. ABOU ARAB, N.M.

E-mail address: alimohamedphd@gmail.com

Present address: Food Control Dep. Animal Health Research Institute-Benha Branch. residues have exceeded the WHO maximum residual levels (MRLs) in many cases. (Darwish et al., 2013). Animal derived foods must not released for human consumption before expiration of with drawl time of therapeutic antibiotics. The with drawl time (WDT) is the period of time required after completion of treatment needed for tissue concentrations of the drug and/or its metabolites to deplete to less than the established MRLs. The final elimination phase depends on drug pharmaceutical formulation, dose, length of treatment, route and site of administration. According to this, a formulation may require a longer WDT when the drug is slowly depleted from tissues. Otherwise, a shorter WDT can be used when faster depletion is adequately proven (Kukanich et al., 2005).

Tilmiscosin is a brood-spectrum macrolide antibiotic. It is synthesized from Tylosin for veterinary use only and has a stronger antimicrobial activity than Tylosin.

It is predominantly effective against Mycoplasma spp., Pasteurella haemolyticus, P. multocida and various Gram positive infections in chicken. (Ose, 1987; Prescott, 2000 and Zhang et al., 2004). It is advised to be the drug of choice in respiratory infections (CRD) treatment and prevention in broilers derived from positive breeders (Jordan et al., 1999; Abu-Basha et al., 2007 and Amer et al., 2012). Continuous administration of Tilmicosin after 2 
rounds of intensive antibiotic treatment with Chlortetracycline, Doxycycline and Enrofloxacin reduced Mycoplasma synoviae shedding from the Mspositive flocks and eventually eradicated $M s$ from the farm (Hong et al., 2015).

This work was conducted to monitor Tilmicosin and Enrofloxacin residues levels in broiler chicken muscles and liver in Benha city, Kaluobia governorate, "Egypt" and study the effects of some heat treatment processes on them to ensure safety chicken for human consumption.

\section{MATERIALS AND METHODS:}

\section{Collection of samples:}

Fourty samples of broiler chicken muscles and liver "twenty samples for each" were collected randomly from popular markets of Benhacity, transmitted to the Lab and apply the analytical procedures.

\section{Sample preparation for Tilimicosin analysis.}

Broiler chicken liver and muscle samples were minced and homogenized in a homogenizer for $2 \mathrm{~min}$. Five grams of homogenate was accurately weighed into a polypropylene centrifuge tube.

\section{Tilmicosin residues extraction}

Extraction of Tilmicosin residues was carried out according to Zhang et al. (2004) and Said et al. (2016)

Ten $\mathrm{ml}$ of acetonitrile were added to the homogenized sample in the centrifuge tube then shaked for $20 \mathrm{~min}$ and centrifugated for $10 \mathrm{~min}$. at $3500 \mathrm{rpm}$ were carried out. The supernatant was transferred into a $50 \mathrm{ml}$ polypropylene centrifuge tube. Five milliliters of monobasic potassium phosphate buffer and $8 \mathrm{ml}$ of acetonitrile were added to the tissue pellet and thorough shaked of the mixture for $20 \mathrm{~min}$. The mixture was centrifugated for $10 \mathrm{~min}$. at $3500 \mathrm{rpm}$ followed by combination of supernatant with $40 \mathrm{ml}$ of HPLC water. The mixture solution was subjugated to centrifugation at $3500 \mathrm{rpm}$ for $10 \mathrm{~min}$. The supernatant was introduced to solid phase extraction (SPE) cleanup step. The SPE was conditioned with 10 $\mathrm{ml}$ of methanol then $10 \mathrm{ml}$ of deionized water and the sample was applied to the cartridge. The flow rate was not more than 2 drops/s. The cartridge was not allowed to dry at this step, so the cartridge was flushed with $10 \mathrm{ml}$ water then $10 \mathrm{ml}$ of acetonitrile. The SPE cartridge was dried for at least $3 \mathrm{~min}$. under vacuum. Elution was performed successively with $2.5 \mathrm{ml}$ ammonium acetate $(0.1 \mathrm{~mol} / \mathrm{L}) /$ methanol / acetonitrile solution. The eluted solution was evaporated until dryness by a nitrogen stream at $30^{\circ} \mathrm{C}$ in a water bath. The sample was reconstituted by $1 \mathrm{ml}$ dipotassium hydrogen phosphate buffer, mixed and filtered through 0.45 um filters before injection into HPLC. Liquid chromatography operating conditions was adjusted for $100 \mathrm{UL}$ injected volume, flow rate, $0.7 \mathrm{ml} / \mathrm{min}$; wave length, $287 \mathrm{~nm}$, column temperature, ambient, stop time: $30 \mathrm{~min}$, post time: 6 min. The mobile phase A was $0.05 \%$ trifluoroacetic acid while mobile phase B was acetonitrile (gradient conditions) as at 0 minute $71 \%$ from mobile phase A and $29 \%$ from $\mathrm{B}$ and at $11 \mathrm{~min}, 54.5 \%$ from $\mathrm{A}$ and $45.5 \%$ from B.50\% was taken from mobile phase A and the same from B at 11.5 and 14 minutes. Tilmicosin standard concentrations of $0.05,0.1,0.2$, $0.5,1.2$ and $5 \mathrm{Ug} / \mathrm{ml}$ were preparated after said et al. (2016).

\section{Enrofloxacin residues extraction:}

The method was carried out according to the technique recommended by Salehzadeh et al. (2007).

\section{Sample preparation}

The samples were kept at - 20 degrees centigrade until analysis.

$2.5 \mathrm{gm}$ of liver or muscle allowed to defrost at room temperature, then $300 \mathrm{mg}$ liver and $400 \mathrm{mg}$ muscle tissues were homogenized. The homogenized extract was centrifuged at $4400 \mathrm{c}$ for $10 \mathrm{~min}$. at $4^{\circ} \mathrm{C}$, repeat extraction step twice and supernatants were pooled. Muscle tissue extract was left at $35^{\circ} \mathrm{C}$ for $15 \mathrm{~min}$. and then centrifuged at $4400 \mathrm{c}$ for $20 \mathrm{~min}$ at $4^{\circ} \mathrm{C}$ and finally filtered by syringe filter.

\section{Sample clean-up by solid-phase extraction:}

An SPE cartridge SPE-pakvac 1 cc (100mg) was conditioned with $2.5 \mathrm{ml}$ of methanol and $2.5 \mathrm{ml}$ of HPLC - grade water. The final extract $(14 \mathrm{ml})$ was applied into the cartridge. When completing the extract loading, the cartridge was washed consecutively with $3 \mathrm{ml}$ of HPLC-grade water, $3 \mathrm{ml}$ of $0.2 \mathrm{M} \mathrm{Na}_{2} \mathrm{HPO} 4$ (PH9) and $5 \mathrm{ml}$ of HPLC-grade water. The cartridge was subsequently dried by air aspiration. Enrofloxacin was eluted with $3.5 \mathrm{ml}$ of $\mathrm{MeoH}$, the elute was evaporated to dry under nitrogen stream. The dry residue was redis solved in $200 \mathrm{ml}$ of $0.2 \mathrm{M} \mathrm{Na} \mathrm{Na}_{2} \mathrm{HPO}$ (PH9). The test tube was vortexmixed for 30 second and then centrifuged at 4400c for $5 \mathrm{~min}$. at $4^{\circ} \mathrm{C}$. The supernatant was transferred to an injection vial and $30 \mathrm{ml}$ was injected into the HPLC system.

Enrofloxacin determination was performed by using a HPLC system consisting of a waters prep Lc4000 and a spectroflow $783 \mathrm{UV}$-vis detector. The detection wave length was set at $277 \mathrm{~nm}$ and the mobile phase used was water - CAN - TEA C83:14:0.45 V/V. The flow-rate was $1 \mathrm{ml} / \mathrm{min}$.

Preparation of standard stock and working solutions: stock solutions of Enrofloxacin were prepared after Salehzadeh et al. (2007). 


\section{Effect of Heat treatment on residues.}

$20 \mathrm{gm}$ of 8 liver samples which contain the maximum levels of Tilmicosin and Enrofloxacin residues (4 for each) were placed in straners and exposed to boiling for 30 minutes and autoclave for 15 minutes under atm. pressure 1.5. (2 samples were exposed to boiling and 2 to autoclave of each antibiotic residue type).

\section{RESULTS}

Table 1: Mean concentration of Tilmicosin and Enrofloxacin residues (ppb) in liver and muscle samples (20 for each)

\begin{tabular}{lcc}
\hline Antibiotic residue & \multicolumn{2}{c}{ Examined tissue } \\
\hline Tilmicosin & Liver & Muscles \\
\hline Mean $\pm \mathrm{SD}(\mathrm{PPb})$ & $481.88 \pm 54.81$ & $\mathrm{ND}$ \\
\hline$\%$ of Tilmicosin Positive Samples & 100 & 0 \\
\hline$\%$ of Tilmicosin-Positive Samples over MRL & 0 & 0 \\
\hline Enrofloxacin & Liver & Muscles \\
\hline Mean $\pm \mathrm{SD}(\mathrm{PPb})$ & $8.288 \pm 1.47$ & $\mathrm{ND}$ \\
\hline$\%$ of EnrofloxacinPositive Samples & 66.66 & 0 \\
\hline$\%$ of Enrofloxacin-Positive Samples over MRL & 0 & 0 \\
\hline
\end{tabular}
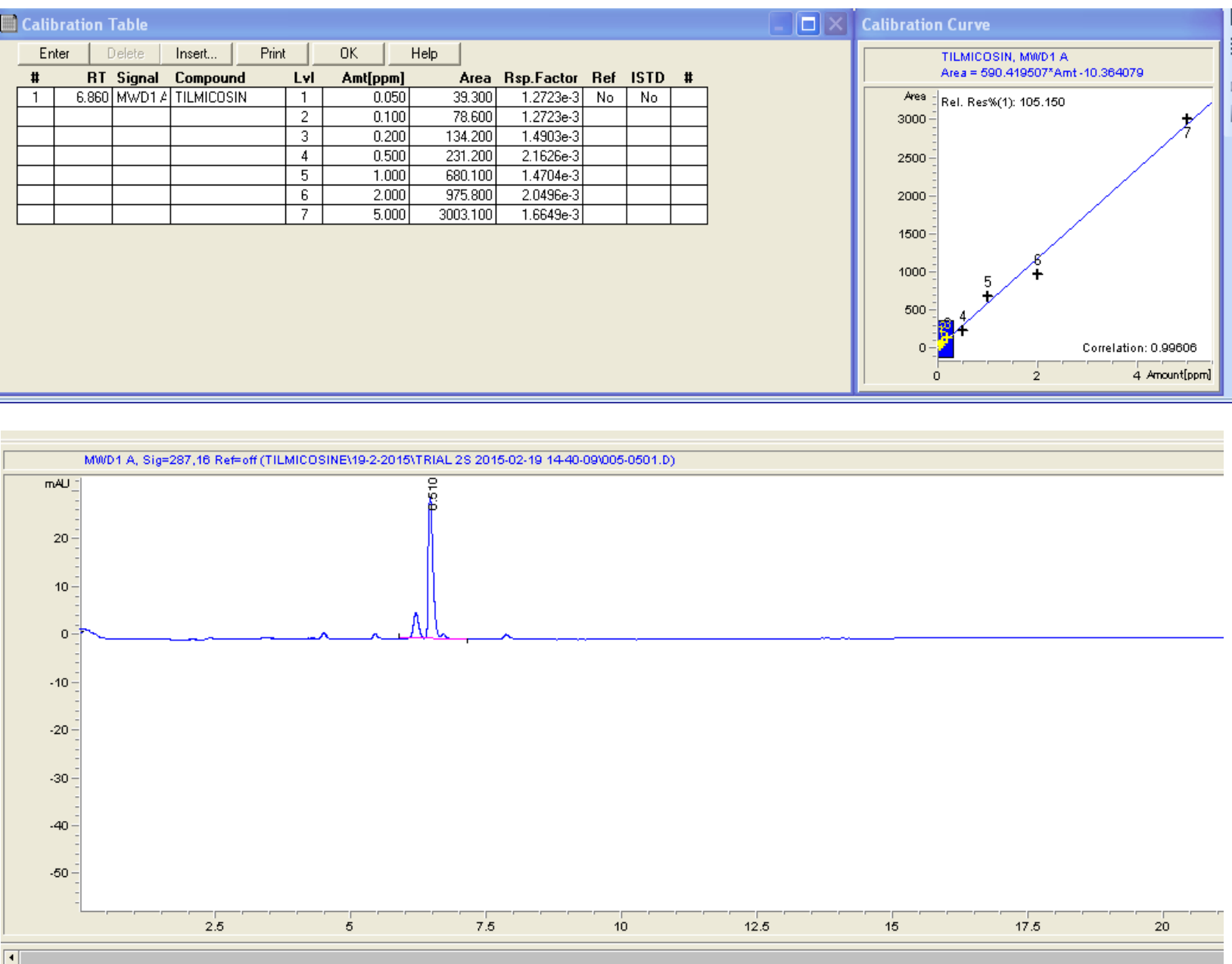

Figure 1: Calibration curve, table and chromatogram of Tilmicosin standard std $0.5 \mathrm{ug} / \mathrm{g}$ 

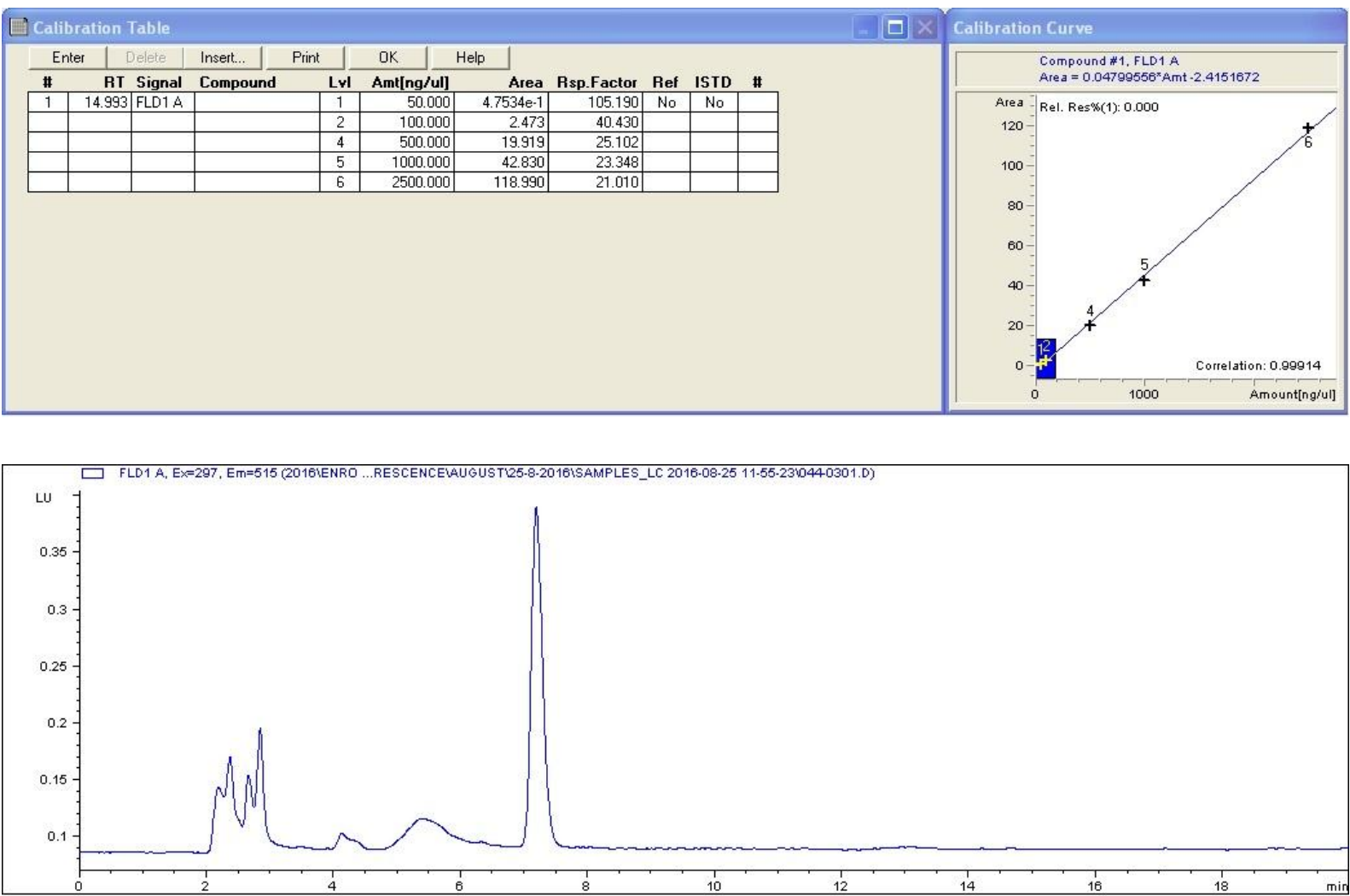

Figure 2: Calibration Curve, table and Chromatogram of Enrofloxacin extract of broiler liver after using of autoclave for $15 \mathrm{~min}$.

The results of this study (Table 1) indicated that Tilmicosin was detected in all liver samples while Enrofloxacin was detected in only $66.66 \%$ of liver samples. Tilmicosin and Enrofloxacin redisues were undetectable in all muscle samples. The mean Tilmicosin concentration was $481.88 \pm 54.81 \mathrm{PPb}$. while mean Enrofloxacin concentration was $8.288 \pm$ 1.47 PPb in liver samples.

\section{Effect of heat}

After heat treatment (boiling for $30 \mathrm{~min}$. and autoclaving for $15 \mathrm{~min}$. under atm. pressure 1.5) of the highest levels positive samples for Tilmicosin and Enrofloxacin residues, all heat treated samples were negative and didn't show any detectable concentrations after analysis with the same procedure.

\section{DISCUSSION}

Extensive use of antibiotics during chicken breeding leads to their residues problem. This problem is the focus of public health concern which introduces a serious and novel hazard to the human beings. The residues comprises the non-altered parent compound, metabolites and or conjugates (Haagsma, 1993).

Extensive administration of Tilmicosin not only leads to residues in the chicken tissues but also resistance of the microorganisms. So, Gerchman et al. (2011) found that $72 \%$ of the strains of Mycoplasma gallisepticum isolated from chinical samples since 2006 showed acquired resistance to Tilmicosin.

The problem of antibiotic residues in feedstuffs is currently of some magnitude in different parts of the world, particularly due to associated public health concerns that include hyper sensitivity, hepatotoxicity, teratogenicity and carcinogenicity (Darwish et al., 2013). Also, human exposure to animal products containing significant level of antibiotic residues may proven immunological response in susceptible individuals and cause disorder of intestinal flora Salehzadeh et al. (2007). Drug residues mainly caused by improper use or insufficient withdrawal period (WDT). These residues accumulated in edible parts of the food producing animals as in tissues or milk at concentration levels higher than the maximum residual levels (MRL). According to the veterinary drug residue regulations of the Chinese ministry of Agriculture and the European Union, the maximum residue levels (MRLs) of Tilmicosin in broiler chicken muscles, liver and kidney are $0.075,1.0$, and $0.25 \mathrm{Ug} / \mathrm{g}$, respectively and the recommended withdrawal time is 10 days (Zhang et al., 2004). The obtained results in table 1 indicated that all liver samples were contained Tilmicosin residues below the maximum residual levels with a mean value of $481.88 \pm 54.81 \mathrm{PPb}$. This result was in accordance or similar to that of Yamaguchi et al. (2015) who 
analyzed 28 antibiotic residues using a LC-Ms/Ms screening method and detected Tilmicosin residues at ranges of $150-450$ micro $\mathrm{g} / \mathrm{kg}(\mathrm{PPb})$ in chicken samples, muscle samples were free or contain undetectable levels of Tilmicosin residues.

Enrofloxacin residues also were detected only in liver samples with a mean value of $8.288 \pm 1.47 \mathrm{PPb}$, while muscle samples didn't give any detectable values. The European commission has established MRLs of the sum of Enro and Ciprofloxacin (one of Enrofloxacin metabolites) for chicken muscle and liver tissues with 100 micro g/kg and 200 micro g/kg respectively, while Japan has defined in all chicken tissues MRLs of $10 \mathrm{micro} \mathrm{g} / \mathrm{kg}$. (Ministry of Health and welfare, 2005). The fixed MRL for Enrofloxacin by VMD (Veterinary Medicine Directorate) of the European union is $30 \mathrm{ng} / \mathrm{g}$. (Salehzadeh et al., 2007).

On the other hand, four days withdrawal period is the allowed time for Enrofloxacin concentration to decrease to an acceptable level (below MRL) in the chicken meat and liver prior to slaughter. (Petrovic et al., 2006).

After four days withdrawal period, most of the metabolites were excreted but residues of Enro and Ciprofloxacin still persisted in tissues at a concentration below the MRL. (Morales-Gutierrez et al., 2015).

The obtained results in the present study declared that the mean residual level of broiler chicken liver samples was below the MRLs, while muscle samples were free or may contain undetectable residues.

These results disagreed with Salehzadeh et al. (2007) who detected Enrofloxacin residual levels above the MRLs in muscle, liver and kidney.

Absence of the residues from the chicken muscles was in accordance with the result of Amjad et al. (2005) who screened quinolones residual antibiotics in broiler muscle, kidney and liver samples and found that Enrofloxacin residues were absent in all samples. These results of the residual levels of Tilmicosin and Enrofloxacin in broiler chicken liver which were below the MRLs may because of slaughtering of the birds at the end of the withdrawal times of both antibiotics.

Absence of Enrofloxacin and Tilmicosin residues in examined muscle samples may be because of not all tissues incorporate antibiotics at the same concentrations. Among poultry tissues, liver had the highest level of antibiotic residues in comparison to other tissues and organs (Sattar et al., 2014). They found that Enrofloxacin residues were $40 \%$ in liver, $34 \%$ in kidneys, $22 \%$ in thigh muscles and $18 \%$ in breast muscles.
For Tilmicosin, Fricke et al. (2008) reported that the highest level of Tilmicosin was found in liver followed by kidney, lungs and muscles. Also, Zhang et al. (2004) found that Tilmicosin residual levels were highest in liver and lowest in muscle which suggested that liver should be the targest tissue for Tilmicosin residues in broiler chickens. They mentioned that Tilmicosin residues were eliminated from muscle very quickly but from liver very slowly. They found that Tilmicosin residue in muscle decreased to the approved level 2 days of withdrawal time while in liver after 9 days. So, Said et al. (2016) found that Tilmicosin could not be detected at the $9^{\text {th }}$ day after the last dose except in liver.

After heat treatments (Boiling and using of autoclave) all samples were free from the residues. This result was inaccordance with that of Haagsma (1993) who stated that the content of residues of many veterinary drugs decreased as a result of food preparing and processing. Also, inaccordance with khan et al. (2015) who found that the maximum depletion of ciprofloxacin occurred after boiling and frying followed by grilling and steaming of broiler meat. The same with Aboul El Nile (2006) who studied the effect of boiling for 30 minutes on Ciprofloxacin residues in chicken tissues and found that boiling process had good effects in decreasing or disappearing of residues. Also, Javadi et al. (2011) analyzed chicken samples contained Enrofloxacin residues after various cooking procedures and detected reduction in their concentration. They found that the most reduced residues in the cooked meat samples were related to boiling process and for cooked liver samples were related to roasting process while the highest detectable amount of residues belonged to microwaving process in all cooked samples. They also found that cooking time and temperature could play major roles about antibiotic residues reduction.

For Tilmicosin, the recorded results were similar to that of Heshmati et al. (2014) who found that cooking processes load to reduction in Tilmicosinresidues levels and reduction amount might differ according to various cooking methods. They found that in boiling method, Tilmicosin reduction percentage became more by increasedtime. However, it was inversely related to Tilmicosin initial concentration. Also the results were inaccordance with Hassan (1995) who reported that boiling of chicken tissues and organs contain Tylosine residues for 30 minutes completely degraded Tylosine residues in all tissue samples.

\section{CONCLUSION}

Great care must be taken to espies antibiotic withdrawal time before slaughtering of the birds and 
release them for human consumption. Also, strict legislation must be implemented to minimize the aduse of antibiotics. Heat processes especially boiling for long periods or using cookers with pressure may be profitable for minimizing antibiotic residues.

\section{REFERENCES}

Abou El-Nile (2006): Effect of boiling and freezing on ciprofloxacin residues in chicken tissues. Assiut Vet. Med. J. Vol. 52 No.110 PP: 111120.

Abu-Basha, E.A.; Idkaidek, N.M. and Al Shunnaq, A.F. (2007): Pharmacokinetics of Tilmicosin (Provitil powder and pulmotil liquid AC) oral formulations in chickens. Vet. Res. Commun, 31 (4): 477-485.

Amer, M.M.; Zohair, G.A.; El-Bayomi, Kh.M. and Girh Z.M.S.A. (2012): Effect of Tilmicosin in control of mycoplasmosis in broiler chickens from infected breeders using ELISA test for evaluation. The journal of American Science; 8 (3): 696-700.

Amjad, H.; Iqbal, J. and Naeem, M. (2005): Analysis of some residual antibiotics in muscle, kidney and liver samples of broiler chicken by various methods. Pakistan Acad. Sci., 42 (4): 223-231.

Darwish, W.S.; Eldaly, E.A.; El-Abbasy, M.T.; Ikea aka, Y.; Nakayama, S. and Ishizuka, M. (2013): Antibiotic residues in food: the African scenario, Japanese journal of veterinary research 61 (supplement): 813-822.

Fabrega, A.; Sanchez-Cespedes, J.; Soto, S. and Vila, $J$. (2008): Quinolone resistance in the food chain. International journal of Antimicrobial agents, 31, 307-315.

Fricke, J.A.; Clark, C.R.; Boison, J.O.M.; ChirinoTrejo, T.E.; Inglis, S. and Dowling, P.M. (2008): Pharmacokinetics and tissue depletion of Tilmicosin in turkeys. J. Vet. Pharmacolther, 31 (6): 591-594.

Gerchman, I.; Levisohn, S.; Mikula, I.; Manso-silvan, L.; Lysnyansky, I. (2011): Characterization of in vivo-acquiredresistance to macrolides of Mycoplasmagal lisepticum strains isolated from poultry. Veterinary research 42 (90).

Haagsma, N. (1993): Stability of veterinary drug residue during storage. Preparation and processing of the Euro residue II conference veldhoven. The Netherlands1: 41-49.

Hassan, M.M.N. (1995): Some antibacterial residues in chicken meat. M.V.SC. Thesis Cairo University (pharmacology).

Heshmati, A.; Salaramoli, J.; Kamkar, A.; Hassan, J. and Jahed, Gh. (2014): Experimental study of the effects of cooking methods on Tilmicosin residues in chicken. Journal of Veteringary Research. 69, 3: 283-290.

Hong, Y.H.; Kwan JI Seon; Lee Hyunjeong; Song Chang Seon and Lee Sangwon (2015):
Eradication of Mycoplasma synoviae from a multi-age broiler breeder farm using antibiotics therapy. Poultry science94 (10): 2364-2368.

Javadi, A.; Mirzaie, H. and Khatibi, S.A. (2011): Effect of roasting, boiling and microwaving cooking methods on Enrofloxacin residues in edible tissues of broiler. African journal of pharmacy and pharmacology, 5 (2) P.P: 214218.

Jordan, F.T.; Forrester, C.A.; Hodge, A. and ReeveJohnson, L.G. (1999): The comparison of an aqueous preparation of Tilmicosin with Tylosin in the treatment of Mycoplasma gallisepticum infection of turkey poults. Avaian Dis. 43 (3): 521-525.

Khan, M.I.; Ashad, M.I.; Arshad, M.S.; Anjum, F.M.; Adnan Riasat; Farhan Saeed; Shahzad Hussain and Muhammad Sohaib (2015): Assessment of different cooking techniques on residual of different cooking techniques on residual of different cooking techniques on residual quantification of ciprofloxacin and Enrofloxacin antibiotics in chicken. J. of Food Processing and Preservation 39 (6): 23792385.

Kukanich, B.; Gehring, R.; Webb, A.; Craigmill, A. and Riviere, J. (2005): Effect of formulation and route of administration on tissue residues and withdrawal times. Journal of the American Veterinary Medical Association, 227, 15741577.

Martinez, M.; McDermontt, $P$. and Walker, $R$. (2006): Pharmacology of the Fluoroquinolones: A perspective for the use in domestic animals, The Veterinary Journal 172, $10-28$.

Ministry of Health and Welfare (2005): Specifications and standards for food, food additives. Notification No. 499. Ministry of Health and Welfare, Tokyo. Japan.

Morales-Gutierrez, F.J.; Barbosa, J. and Barron, D. (2015): Metabolic study of Enrofloxacinand metabolic profile modifications in broiler chicken tissues after drug administration. Food Chemistry172: 30-39.

Ose, E.E. (1987): In vitro antibacterial properties El870, a new semisynthetic macrolide antibiotic J. Antibiot. 40 (2): 190-194.

Petrovic, J.; Baltic, M.; Cupic, V.; Stefanovic, S. and Stojanovic, D. (2006): Residues of Enrofloxacin and its main metabolite Ciprofloxacin in broiler chickens. Act Veterinaria (Beograd), 56 (5-6): 497-506.

Prescott, J.F. (2000): Macrolides and pleuromyilins. Antimicrobial therapy in Veterinary Medicine, $3^{\text {rd }}$ edn. (Iowa State University Press, Ames, USA), PP: 229-262.

Said, A.A.; El Nabtity, M.S.; Selim, M.A.A. and fadel, A. Mai (2016): Detection of Tilmicosin residues by HPLC and its effect on cardiac 
enzymes and hematology in broiler chickens. Zagazig veterinary journal volume 44, Number 1, P.29-39.

Salehzadeh, F.; Aref, S.; Nordehr, R.; Rahim, M. and Fariba, G. (2007): Enrofloxacin residue in chichen tissues from Tehran slaughterhouses in Iran, Pakistan Journal of Nutrition 6 (4): 409413.

Sattar, S.; Hassan, M.M.; Islam, S.K. M.A.; Alam, M.; Faruk, M.S.A.; Chowdhury, S. and Saifuddin, A.K.M. (2014): Antibiotic residues in broiler and layer meat in chittagong district of Bangladesh. Veterinary World, 7 (9): 738743.

Stephen, F. and Sundlof, D.V.M. (1994): Human risks associated with drug residues in animal derived food. J. Agromedicine. 1 (2): 5-20.

Weaver, L.D. (1992): Antibiotic residues in milk and meat precipitations and realities. J. Vet. Med 87: 1222-1228.
Yamaguchi, T.; Okihashi, M.; Harada, K.; Konishi, Y.; Uchida, K.; Mai Houng Ngoc Do; Huong Danf Thien Bui; Thinh Duc Nguyen; Phuc Do Nguyen; Vien Van Chau; Khanhthi van Dao; Hue Thi Ngoc Nguyen; Kajimura, K.; Kumeda, Y.; Chien Trong Bui; Mai Quang Vien; Ninh Hoang Le; Hirata, $K$. and Yamamoto, $Y$. (2015): Antibiotic residue monitoring results for pork, chicken, and beef samples in Vietnam in 2012-2013. Journal of Agricultural and Food Chemistry; 63 (21): 5141-5145.

Yorke, J.C. and Froc, P. (2000): Quantitation of nine quinolones in chicken tissues by HighPerformance Liquid Chromatography with fluorescence detection. J. Chramatography A, 882: 63-77.

Zhang, Y.; Jiang, H.; Jin, X.; Shen, Z.; Shen, J.; Fu, C. and Guo, J. (2004): Residue depletion of Tilmicosin in chicken tissues. J. Agric. Food Chem., 52 (9): 2602-2605.

\section{الكشف عن متبقيات التلميكوزين والإنروفلوكساسين في كب ولحوم دجاج التسمين المباعة بالأسواق بمدينة بنها

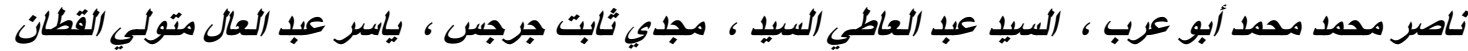

Email: alimohamedphd@gmail.com Assiut University web-site: www.aun.edu.eg

تم تجميع • ع عينة من كبد و عضلات دو اجن اللحم (·r عينة لكل منها) من الأسواق الثعبية بمدينة بنها (مصر) وذلك لاكتشاف

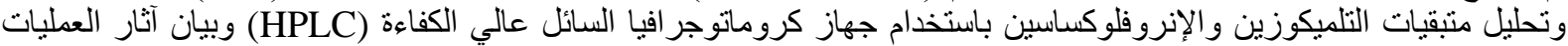

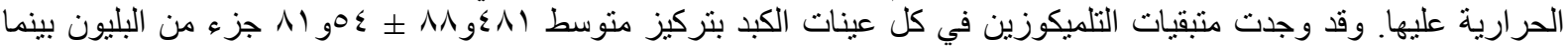

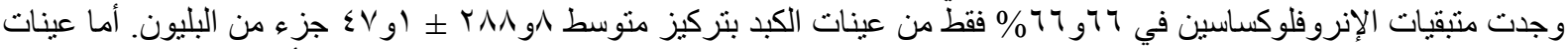

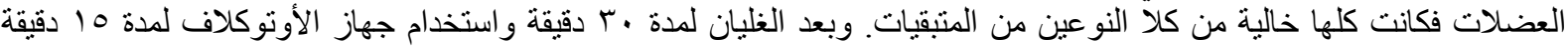

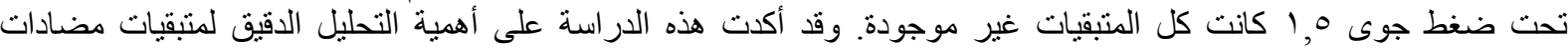
الميكروبات فبل تسويقها وكذلك أكدت جدوى الطبخ الحراري باستخدام الضغط أو بدونه في الاختفاء الكلي أو الجزئي للمنبقيات. 